Japan. J. Med. Sci. Biol., 36, 315-323, 1983

\title{
SEROLOGICAL STUDIES ON VIBRIO FLUVIALIS
}

\author{
Toshio SHIMADA and RIIcHI SAKAZAKI \\ The First Department of Bacteriology, National Institute of Health \\ Kamiosaki, Shinagawa-ku, Tokyo 141
}

(Received August 27, 1983. Accepted October 19, 1983)

\begin{abstract}
SUMMARY: The serology of 138 strains of Vibrio fluvialis was studied. Eighteen $\mathrm{O}$-antigenic groups were defined among them and it was shown that the $\mathrm{H}$ antigens of all the strains were identical regardless of the biovar. The presence of mucoid antigen, which inhibits $\mathrm{O}$ agglutination, was found in some strains. As all $\mathrm{O}$ antisera for $V$. fluvialis contained some $R$ antibody, all diagnostic $O$ sera must be absorbed with $\mathrm{R}$ organisms before use. Some $\mathrm{O}$ antigens of $\boldsymbol{V}$. fuvialis were identical with those of certain Vibrio cholerae serovars.
\end{abstract}

\section{INTRODUCTION}

Vibrio fluvialis, previously known as "group F vibrio" in England and "CDC group EF6" in the United States (Furniss et al., 1977; Huq et al., 1980), is a halophilic marine organism. It has been isolated from estuarine water and seafish (Furniss et al., 1977; Lee et al., 1978; Seidler et al., 1980; Sakazaki, 1982) and from numerous patients suffering from acute diarrhea (Spira et al., 1978; Blake et al., 1980; Furniss et al., 1977; Huq et al., 1980; McNicol et al., 1980; Seidler et al., 1980; Agarwal and Sanyal, 1981; Sakazaki, 1982; Tacket et al., 1982). Recently, several reports on the enteropathogenicity of the organism have appeared (Sanyal et al., 1980; Seidler et al., 1980; Lockwood et al., 1982; Kobayashi et al., 1983; Kudoh et al., 1983; Nishibuchi et al., 1983). However, no serological study of this organism has so far been described. The purpose of the present study, in which 138 strains of the organism isolated from various sources were examined, is to propose an antigenic schema for epidemiological and ecological use.

\section{Materials ANd Methods}

Strains studied: A total of 138 strains of $V$. fluvialis was studied; of these 104 were isolated in Japan, 23 were received from India, eight from Bangladesh and three from Africa. Of the 138 strains, 112 were $V$. fluvialis biovar I, and the remaining 26 strains were biovar II. The majority of the strains were isolated either from the feces of patients with gastroenteritis or from seafish, and a few were derived from birds and seawater. An $\mathrm{R}$ antigen mutant derived

島田俊雄・坂崎利一（国立予防衛生研究所 細菌第一部） 
from strain GF25 was obtained after repeated colony selection by an oblique light method.

In addition, other 124 strains of related species including Vibrio cholerae, $V$. parahaemolyticus and Plesiomonas shigelloides were used to study their antigenic relationship to $V$. fluvialis.

$O$ antisera: For preparation of the $\mathrm{O}$ antisera, strains were inoculated into infusion broth. After overnight incubation at $37 \mathrm{G}$ with continuous shaking in a water bath, the cultures were heated at $100 \mathrm{C}$ for $2 \mathrm{hr}$. The heated organisms were then washed twice and, after final centrifugation, the packed cells were resuspended in saline. The density of the suspension was adjusted to that of the original broth culture. Rabbits were each injected intravenously with 0.5-, 1-, 2- and 4-ml amounts of the suspension at intervals of 4 days. The animals were bled on the sixth day after completion of the course of injections and the serum separated.

$H$ antisera: Crude flagellar preparations were used for production of the $\mathbf{H}$ antisera. Actively motile cultures, obtained by several passages of the organism through semisolid media, were inoculated into brain heart infusion (Difco). After incubation at $37 \mathrm{G}$ for $18 \mathrm{hr}$, the growth was centrifuged at $15,000 \mathrm{rpm}$ for $30 \mathrm{~min}$ and the sediment washed twice in saline. The packed cells were resuspended in saline and deflagellated in a blender at 8,000 rpm for $5 \mathrm{~min}$. After deposition of the cells by centrifugation at $15,000 \mathrm{rpm}$ for $30 \mathrm{~min}$, the supernatant fluid was removed and then centrifuged at 70,000 $\times \mathrm{g}$ for $60 \mathrm{~min}$; the sediment was washed twice in saline. The presence of flagellar fragments in this sediment was confirmed by electron microscopy. The flagellar fragment obtained from a 1-liter culture was suspended finally in $20 \mathrm{ml}$ of phosphate buffered saline $(0.067 \mathrm{M}, \mathrm{pH} 7.2)$. Rabbits were each immunized with each of these suspensions in the same way as that for the preparation of $O$ antisera. Since only crude flagellar preparations were used for immunization, $\mathrm{O}$ antibody in the resulting $\mathrm{H}$ antisera was removed by absorption with the homologous culture heated at $100 \mathrm{C}$ for $2 \mathrm{hr}$.

Agglutination tests: For antigen determination, tube agglutination tests were carried out with heated cell suspension as used for preparation of $\mathrm{O}$ antisera. The results were read after incubation in a water bath at $50 \mathrm{C}$ for $18 \mathrm{hr}$. The $\mathrm{H}$ agglutination tests were performed with suspensions of motile cultures. Antigens for the tube agglutination tests were prepared from 18-hr cultures on Trypticase Soy Agar. The cultures were harvested in saline containing $0.3 \%$ formalin. The density of the suspension was adjusted to that of an overnight broth culture. The H-agglutination tests were carried out by mixing equal volumes of antigen with appropriate dilutions of sera; the results were read after incubation in a water bath at $50 \mathrm{C}$ for $18 \mathrm{hr}$. For R-agglutination tests, the $\mathbf{R}$ antigen culture was suspended in distilled water, and an equal volume of the suspension was added to diluted antisera with $0.85 \%$ saline to prevent autoagglutination.

Agglutinin-absorption tests: Agglutinin-absorption tests were performed 
when reciprocal or unilateral reactions occurred with certain antisera. Diluted antiserum was mixed with packed cells derived from growth on plates of infusion agar for absorption of $\mathrm{O}$ antisera and on Nutrient Broth No. 2 (Oxoid) containing $1 \%$ agar (Difco) for $\mathrm{H}$-antibody absorption.

TABLE I

Agglutinability of $O$ antigen suspensions

\begin{tabular}{|c|c|c|}
\hline Strain & Treatment & O titer to homologous antiserum \\
\hline & 1 & 80 \\
\hline \multirow[t]{3}{*}{ GF1 } & 2 & 80 \\
\hline & 3 & 320 \\
\hline & 1 & 80 \\
\hline \multirow[t]{3}{*}{ GF3 } & 2 & 80 \\
\hline & 3 & 1,280 \\
\hline & 1 & 40 \\
\hline \multirow[t]{3}{*}{ GF4 } & 2 & 40 \\
\hline & 3 & 1,280 \\
\hline & 1 & 40 \\
\hline \multirow[t]{3}{*}{ GF5 } & 2 & 40 \\
\hline & 3 & 640 \\
\hline & 1 & 320 \\
\hline \multirow[t]{3}{*}{ GF6 } & 2 & 320 \\
\hline & 3 & 640 \\
\hline & 1 & 80 \\
\hline \multirow[t]{3}{*}{ GF9 } & 2 & 80 \\
\hline & 3 & 640 \\
\hline & 1 & 80 \\
\hline \multirow[t]{3}{*}{ GF16 } & 2 & 80 \\
\hline & 3 & 640 \\
\hline & 1 & 160 \\
\hline \multirow[t]{3}{*}{ GF21 } & 2 & 160 \\
\hline & 3 & 640 \\
\hline & 1 & 40 \\
\hline \multirow[t]{3}{*}{ GF22 } & 2 & 160 \\
\hline & 3 & 320 \\
\hline & 1 & - \\
\hline \multirow[t]{3}{*}{ GF27 } & 2 & 20 \\
\hline & 3 & 320 \\
\hline & 1 & 20 \\
\hline \multirow[t]{2}{*}{ GF37 } & 2 & 160 \\
\hline & 3 & 640 \\
\hline
\end{tabular}

Treatment 1: Live state

2: Heated at $100 \mathrm{C}$ for $1 \mathrm{hr}$

3: Heated at $100 \mathrm{C}$ for $2 \mathrm{hr}$

The sign - indicates negative at a dilution of $1: 20$ and higher. 
TABLE II

$R$ agglutinin titers of diagnostic $O$ antisera of V. fluvialis

\begin{tabular}{lcc}
\hline & \multicolumn{2}{c}{ Antigen $(100 \mathrm{C}, \mathbf{2} \mathrm{hr})$} \\
\cline { 2 - 3 } Antiserum & GF25(R)* & Homologous O antigen \\
\hline O2 & 160 & 320 \\
O3 & 320 & 640 \\
O4 & 160 & 1,280 \\
O5 & 320 & 1,280 \\
O6 & 160 & 640 \\
O7 & 160 & 640 \\
O8 & 160 & 640 \\
O9 & 160 & 640 \\
O10 & 80 & 640 \\
O11 & 160 & 320 \\
O12 & 160 & 320 \\
O13 & 160 & 640 \\
O14 & 320 & 1,280 \\
O15 & 160 & 1,280 \\
O16 & 160 & 320 \\
O17 & 320 & 320 \\
O18 & 160 & 2,560 \\
\hline
\end{tabular}

* GF 25 was employed as a pilot strain for the $\mathrm{R}$ antigen of $V$. fluvialis.

TABLE III

$O$ antigenic relationships

\begin{tabular}{ccc}
\hline O antiserum* & Homologous titer & Titer with other O antigen \\
\hline O1 & 320 & \\
O2 & 320 & \\
O3 & 320 & \\
O4 & 640 & \\
O5 & 320 & \\
O6 & 640 & \\
O7 & 320 & \\
O8 & 320 & \\
O9 & 320 & \\
O10 & 320 & \\
O11 & 320 & \\
O12 & 640 & \\
O13 & 1,280 & \\
O14 & 640 & \\
O15 & 320 & \\
O16 & 320 & \\
O17 & 1,280 & \\
O18 & 1,280 & \\
\hline
\end{tabular}

* $\mathrm{R}$ antibody in the antiserum was removed by absorption with $\mathrm{R}$ culture (GF25) heated at $100 \mathrm{C}$ for $2 \mathrm{hr}$. 


\section{Results}

\section{O Antigen}

Since some live cultures of $V$. fluvialis did not agglutinate with homologous $O$ antisera, 11 strains were first used to determine the best way of treating cell suspensions for optimal $\mathrm{O}$ agglutinability. Growth on infusion agar at $37 \mathrm{C}$ for $18 \mathrm{hr}$ was harvested in saline and the suspension divided into three parts. One part was retained; another heated at $100 \mathrm{C}$ for $2 \mathrm{hr}$; and the other heated at $100 \mathrm{C}$ for $1 \mathrm{hr}$. The organisms in each part were then washed in saline, centrifuged and the packed cells finally resuspended in saline. Subsequent agglutination tests showed that the antigens heated for $2 \mathrm{hr}$ gave the highest titers with homologous $\mathrm{O}$ antisera; in contrast, no reaction or only weak agglutination occurred with live antigens (Table I). From these results, determinations of the $O$ antigens of the 138 cultures were carried out with the cell suspensions heated at $100 \mathrm{C}$ for $2 \mathrm{hr}$ followed by washing.

As shown in Table II, it was recognized that, although they had been

TABLE IV

$O$ antigen determination and distribution of 138 strains of $\mathrm{V}$. fluvialis

\begin{tabular}{|c|c|c|c|c|c|}
\hline \multirow{2}{*}{ O group } & \multicolumn{4}{|c|}{ Source } & \multirow{2}{*}{ Total } \\
\hline & Human & Seafish & Bird & Seawater & \\
\hline $\mathrm{Ol}$ & 2 & 3 & - & - & 5 \\
\hline $\mathrm{O} 2$ & 1 & 2 & - & - & 3 \\
\hline O3 & 1 & 4 & - & - & 5 \\
\hline $\mathrm{O} 4$ & 8 & 4 & 1 & - & 13 \\
\hline O5 & 1 & 1 & - & - & 2 \\
\hline $\mathrm{O} 6$ & $5(3) *$ & 1 & - & - & $6(3)$ \\
\hline $\mathrm{O} 7$ & $15(4)$ & 2 & - & - & $17(4)$ \\
\hline O8 & 1 & - & - & - & 1 \\
\hline O9 & 3 & 2 & - & 1 & 9 \\
\hline $\mathrm{O} 10$ & $7(2)$ & 3 & - & - & $10(2)$ \\
\hline O11 & $4(2)$ & $4(3)$ & - & - & $8(5)$ \\
\hline $\mathrm{O} 12$ & 1 & - & - & - & 1 \\
\hline 013 & 1 & 4 & - & - & 5 \\
\hline O14 & 4 & 5 & - & - & 9 \\
\hline $\mathrm{O} 15$ & 1 & - & - & - & 1 \\
\hline O16 & 2 & 5 & - & - & 7 \\
\hline $\mathrm{O} 17$ & 1 & 2 & - & 1 & 4 \\
\hline $\mathrm{O} 18$ & 1 & 1 & - & - & 2 \\
\hline UK & - & $7(5)$ & 3 & - & $10(5)$ \\
\hline $\mathrm{R}$ & $5(2)$ & $15(5)$ & - & - & $20(7)$ \\
\hline Total & $64(13)$ & $68(13)$ & 4 & 2 & $138(26)$ \\
\hline
\end{tabular}

* Numbers in parentheses indicate the number of strains of biovar II. 
TABLE V

$H$ agglutinin-absorption tests with $\mathrm{V}$. fluvialis

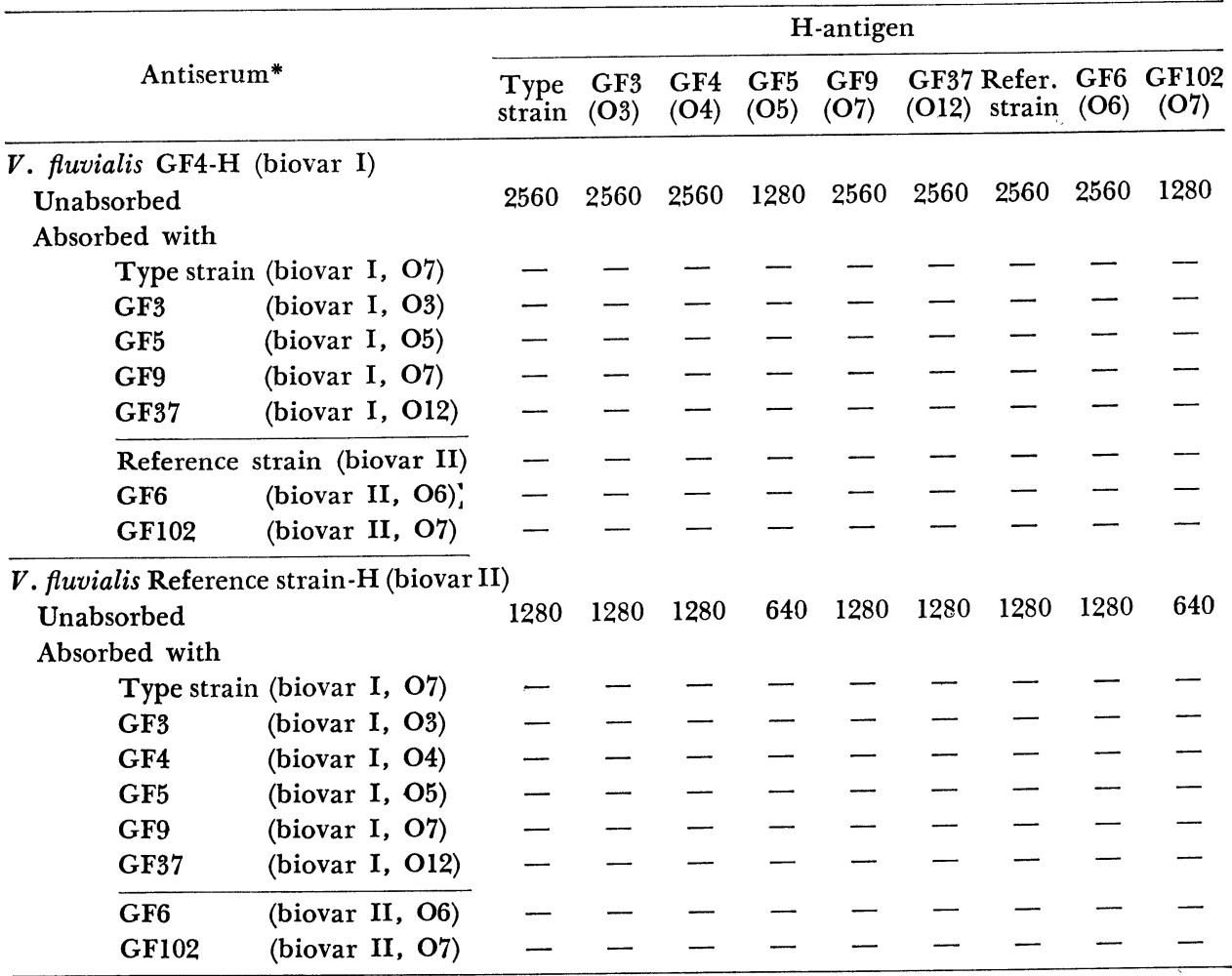

* $O$ antibody in the antiserum was removed by absorption with homologous cultures heated at $100 \mathrm{C}$ for $2 \mathrm{hr}$.

The sign-indicates negative at a dilution of $1: 20$ and higher.

produced with $\mathrm{S}$ cultures, all $\mathrm{O}$ antisera for $V$. fluvialis contained some $\mathrm{R}$ agglutinin.

By cross-agglutination and agglutinin-absorption tests, these cultures except some $\mathrm{R}$ forms and unknown non-reacting strains, were divided into $18 \mathrm{O}$ antigenic groups. As shown in Table III, additional reactions occurred with the antisera of $O$ groups 6 and 14 , but no actual cross-reaction was observed among any combination of the $18 \mathrm{O}$-antigen groups.

The results of O-antigen determinations of the 138 strains of $V$. fluvialis from various sources are summarized in Table IV. Of these, 108 strains were grouped with the $18 \mathrm{O}$ antisera; of the remainders, 20 were R-form cultures and 10 strains did not react with any of the antisera.

\section{$H$ Antigen}

$\mathrm{H}$ antisera were prepared with two cultures, V. fluvialis GF4 (biovar I, O 
TABLE VI

$O$ antigenic relationships between Vibrio fluvialis and $\mathrm{V}$. cholerae serovars

\begin{tabular}{|c|c|c|}
\hline \multirow{2}{*}{ Antiserum } & \multicolumn{2}{|c|}{ Antigen $(100 \mathrm{C}, 2 \mathrm{hr})$} \\
\hline & V. fluvialis-O4 & V. cholerae-O41 \\
\hline \multicolumn{3}{|l|}{ V. fluvialis-O4 } \\
\hline Unabsorbed & 640 & 640 \\
\hline Absorbed with $V$. cholerae-O41 & - & - \\
\hline \multicolumn{3}{|l|}{$V$. cholerae $-\mathrm{O} 41$} \\
\hline Unabsorbed & 640 & 640 \\
\hline \multirow[t]{2}{*}{ Absorbed with $V$. fluvialis-O4 } & - & - \\
\hline & V. fluvialis-O5 & V. cholerae-O39 \\
\hline \multicolumn{3}{|l|}{ V. fluvialis-O5 } \\
\hline Unabsorbed & 320 & 320 \\
\hline Absorbed with $V$. cholerae $-\mathrm{O} 39$ & - & - \\
\hline \multicolumn{3}{|l|}{ V. cholerae-O39 } \\
\hline Unabsorbed & 640 & 640 \\
\hline \multirow[t]{2}{*}{ Absorbed with $V$. fluvialis-O5 } & - & - \\
\hline & V. fluvialis-O10 & V. cholerae-O6 \\
\hline \multicolumn{3}{|l|}{ V. fluvialis-O10 } \\
\hline Unabsorbed & 320 & 320 \\
\hline Absorbed with $V$. cholerae-O6 & - & - \\
\hline \multicolumn{3}{|l|}{$V$. cholerae $-\mathrm{O} 6$} \\
\hline Unabsorbed & 640 & 640 \\
\hline Absorbed with $V$. fluvialis-O10 & - & - \\
\hline
\end{tabular}

The sign-indicates negative at a dilution of $1: 20$ and higher.

group 4) and NCTC 11328 (biovar II reference strain). By cross agglutination and agglutinin-absorption tests with these two $\mathrm{H}$ antisera and nine strains of $V$. fluvialis chosen at random, it was demonstrated that the $\mathrm{H}$ antigens of all nine cultures were identical (Table V).

H-agglutination tests were also carried out with all the strains of $V$. fluvialis received. Of the 138 strains of the organism, 135 were agglutinated with both $\mathrm{H}$ antisera at homologous titers. The remaining three non-motile cultures were not agglutinated. The $\mathrm{H}$ agglutination of $V$. fluvialis cultures was flocculant in nature and it appeared only after incubation at $50 \mathrm{G}$ for $8 \mathrm{hr}$ or longer.

From these results, it is concluded that all the strains of $V$. fluvialis examined in the present study possessed an identical $\mathrm{H}$ antigen.

\section{Extrageneric Relationships}

Antigenic relationships between $V$. fluvialis and other biochemically related organisms including $V$. cholerae, $V$. parahaemolyticus and Plesiomonas shigelloides were investigated. Heated antigen suspensions were prepared with representative cultures of the $18 \mathrm{O}$ groups of $V$. fluvialis, 83 serovars of $V$. cholerae, $11 \mathrm{O}$ groups of $V$. parahaemolyticus and $30 \mathrm{O}$ groups of plesiomonads for cross- 
TABLE VII

Representative strains for serovars of $\mathrm{V}$. fluvialis

\begin{tabular}{cr}
\hline Serovar & \multicolumn{1}{c}{ Strain } \\
\hline 1 & $12-68$ \\
2 & $26-68$ \\
3 & $209-73$ \\
4 & $210-73$ \\
5 & $212-73$ \\
6 & $1997-80$ \\
7 & $305-77$ \\
8 & $99-77$ \\
9 & $910-77$ \\
10 & $1184-77$ \\
11 & $96-79$ \\
12 & $391-79$ \\
13 & $1562-80$ \\
14 & $1988-80$ \\
15 & $1561-80$ \\
16 & $881-81$ \\
17 & $950-82$ \\
18 & $1030-82$ \\
\hline
\end{tabular}

agglutination and agglutinin-absorption tests. Although no significant reciprocal relationships were recognized between the $\mathrm{O}$ antigens of $V$. fluvialis and $V$. parahaemolyticus or plesiomonads, some close relationships were demonstrated between those of $V$. fluvialis and $V$. cholerae. As shown in Table VI, O antigens 4,5 and 10 of $V$. fluvialis were apparently identical with those of $V$. cholerae serovars 41,39 and 6 , respectively.

\section{Discussion}

In the present study, 18 O-antigen groups were defined among 138 strains of $V$. fluvialis. Since all strains of $V$. fluvialis possess identical $\mathrm{H}$ antigens, $\mathrm{O}$ antigen groups of the species should therefore be referred to as serovars. The representative strain for each serovar is shown in Table VII; these strains should be used for preparation of the diagnostic antisera.

The $\mathrm{R}$ form is indistinguishable in colonial morphology from the parent $S$ form, but may be distinguished by agglutination with anti-R serum. All $\mathrm{O}$ antisera against $V$. fluvialis contain some $\mathrm{R}$ antibody which may cause cross reactions in determination of the $\mathrm{O}$ groups. It should be emphasized, therefore, that for practical use all diagnostic $\mathrm{O}$ antisera must be absorbed with $\mathrm{R}$ culture of $V$. fluvialis strain GF25.

Although the mucoid antigens of $V$. fluvialis have not been considered in this study, the majority of strains were $O$ inagglutinable in the living state. For identification of $\mathrm{O}$ antigens, the cultures to be tested should therefore be heated at $100 \mathrm{C}$ for $2 \mathrm{hr}$ and washed twice before examination. 
There was no significant difference in the distribution of serovar strains in man or fish (Table IV).

\section{REFERENCES}

Agarwal, R. K. AND Sanyal, S. C. (1981): Experimental studies on enteropathogenicity and pathogenesis of group 'F' vibrio infections. Zbl. Bakt. Hyg., Abt. Orig., A249, 392-399.

Blake, P. A., Weaver, R. E. AND Hollis, D. G. (1980): Diseases of humans (other than cholera) caused by vibrios. Ann. Rev. Microbiol., 34, 341-367.

Furniss, A. L., Lee, J. V. And Donovan, T. J. (1977): Group F, a new vibrio? Lancet, ii, $565-566$.

HuQ, M. I., Alam, A. K. M., Brenner, D. J. And Morris, G. K. (1980): Isolation of vibrio-like group, EF-6, from patients with diarrhea. J. Clin. Microbiol., 11, 621-624.

Kobayashi, K., Taguchi, M., Shimada, T. and Sakazaki, R. (1983): Ten cases of gastroenteritis possibly caused by Vibrio fluvialis and its enterotoxigenicity. J. Japan. Assoc. Infect. Dis., 57, 375-382.

Kudoh, Y., Tsuno, M., Matsushita, S., Yamada, S., Ohta, K., Sakai, S. and Ohashi, M. (1983): Enteropathogenicity and some biological features of group F (EF-6) vibrio isolates. p. 75-86. In S. Kuwahara and N. F. Pierce [eds.], Advances in Research on Cholera and Related Diarrheas, KTK Scientific Publishers, Tokyo.

Lee, J. V., Donovan, T. J. ANd Furniss, A. L. (1978): Characterization, taxonomy, and emended description of Vibrio metschnikovii. Int. J. Syst. Bacteriol., 28, 99-111.

Lockwood, D. E., Kreger, A. S. AND Richardson, S. H. (1982): Detection of toxins produced by Vibrio fluvialis. Infect. Immun., 35, 702-708.

McNicol, L. A., Kaper, J. B., Lockman, H. A., Remmcrs, E. F., Spira, W. M., Voll, M. J. AND Colwell, R. R. (1980): R-factor carriage in a group $F$ vibrio isolated from Bangladesh. Antimicrob. Agents Chemother., 17, 512-515.

Nishibuchi, M., Seidler, R. J., Rollins, D. M. ANd Joseph, S. W. (1983): Vibrio factors cause rapid fluid accumulation in suckling mice. Infect. Immun., 40, 1083-1091.

SAKAZAKI, R. (1982): Current status of human diseases caused by pathogens associated with seafoods. p. 177-184. In H. Kurata and C. W. Hesseltine [eds.], Control of the microbial contamination of foods and feeds in international trade: Microbial standard and specifications, Saikon Publishing Tokyo.

Sanyal, S. C., Agarwal, R. K., Annapurna, E. And Lee, J. V. (1980): Enterotoxicity of group F vibrios. Japan. J. Med. Sci. Biol., 33, 217-222.

Seidler, R. J., Allen, D. A., Colwell, R. R., Joseph, S. W. And Daily, O. P. (1980): Biochemical characteristics and virulence of environmental group $\mathrm{F}$ bacteria isolated in the United States. Appl. Environ. Microbiol., 40, 715-720.

Spira, W. M., Daniel, R. R., Ahmed, Q. S., HuQ, A., Yusef, A. and Sack, D. A. (1978): Clinical features and pathogenicity of $O$ group 1 nonagglutinating Vibrio cholerae and other vibrios isolated from cases of diarrhea in Dacca, Bangladesh. p. 137-153. In K. Takeya and Y. Zinnaka [eds.], Proceeding of the 14th Joint Conference of the U.S.-Japan Cooperative Medical Science Program, Cholera Panel. Fuji Printing, Tokyo.

Tacket, C. O., Hickman, F., Pierce, G. V. and Mendoza, L. F. (1982): Diarrhea associated with Vibrio fluvialis in the United States. J. Clin. Microbiol., 16, 991-992. 